he appears to have taken an active part in the stirring events of that period, and he lived to see what many another gallant Crusader, "cujus anima requiescat in pace," was not destined to witness, viz., the undisturbed possession by the Christians, in consequence of the remarkable treaty of Frederic II, of Bethlehem and Nazareth, with free access to Jerusalem and the holy sites.

Here I must conclude my notice of him (in hope that others will fill in the outline thus briefly sketched) with the following extract from the chronicle already named, and referring to events happening just before the expulsion of the Christians from Jerusalem by the Sultan of Egypt in 1236 :- "Circa illos dies, nobilis ac Deo devotus in armis strenuus miles, Philippus de Albeneto, postquam militaverat Deo in Terra sancta, peregrinando pluriès, tandem in eadem, diem Claudeus extremum, et finem faciens laudabilem, sanctam meruit in Terra sancta, quod vivus diu desideraverat, sepulturam" (p. 432).

It seems a strange coincidence that of the two Crusaders' tombs which till a year or two year ago were still in situ at Jerusalem, one, which has now disappeared, should, on good historical evidence, have been identified with that of one of the murderers of Thomas à Becket, and the other, still in position and in excellent preservation, that of a soldier and scholar who helped to secure England's Great Charter.

The mediæval tombstone dug up thirteen years ago by Mr. Maudslay is now in the collection of antiquities at the Church of St. Anne.

J. E. Hanaeur.

JERUSALEM,

January 31st, 1887.

\title{
RESEARCHES IN THE PLAIN NORTH OF CAESAREA.
}

By G. Schumacher.

\section{(I.) AN EXCURSION TO THE CROCODILE RIVER.}

WITH the object of hunting up one of those famous crocodiles which are said to be found in the swamps of the Nahr ez Zerka, the Crocodile River of the ancients, near Cæsarea, a specimen of which was killed by the German Colonists in the spring of 1878, and invited by the natives of that district to destroy these enemies, who annually look for a prey out of their flocks and herds, I gathered a few friends of the Colony and camped for a week near the marshes of the said river.

After inquiring about the customary haunt of the crocodiles-a question which was warmly discussed among the members of the Ghawârni tribe of 
the swamps--I chose eight out of the best hunters of them, and, accompanied by six colonists, we began to make our way into the swamps. Our guides were each armed with a primitive rifle, pistols, and knives, bare-footed, and clothed with a long shirt which they tucked up to their knees and fastened in their leather girtle ; their figures were stout, tall, and not unpleasant, their colour pretty dark. Although Moslems by religion, they do not hesitate to hunt, kill, and eat wild boar if they are not able to sell it on the spot to natives going to Haifa. They live amidst the swamps in poor-looking hair-tents, among cane jungles and water pools; they cultivate no soil, but live on buffalo (jammats) milk and cheese, and on the results of their hunting. The climate of their home is much feared for the malaria fever, which is produced by the stagnant waters of the Zerka together with the burning sum, and even a night suffices for a stranger to suffer from it for months ; but the Ghawârni-i.e., "the inhabitants of the Ghôr, or Zôr," "the depression," in which they camp-enjoy these regions to such a degree that an Arab proverb says, "if the Ghôry leaves his marshy camp and comes to Haifa, he gets attacked from fever, for a healthy climate injures his health." If on such an occasion the Ghôry comes back in a feverish condition, he unties his shirt and keffîyeh (headcloth) and wallows in the abundant mud of his vicinity; he then looks for a good dry and hot place, where the sunbeams can reach him without obstacle, stretches himself out and does a good sleep. When he awakes, the mud covering his body has dried up, and when it falls in pieces from him, the Ghôry feels released from his illness. Primitive as this cure may sound, it nevertheless proves to be successful, for the mud-cover withdraws the heat from the body.

The Ghawârui of the Zerka are not numerous ; they live among themselves in good peace, but they are feared by the neighbouring fellahin and Bedouins for their rapacity and boldness, of which many stories can be heard ; they are also not considered to be Moslems, as they do not observe the Mohammedan interdictions as to pork, spirits, and dogs, the latter being their continuous companions.

Our Ghawârni took us first to the Khurbet Kubbâr (خربة كُبار marked "Kebârah" on Sheet VII of the large map of the Fund), and from thence in a south-western direction about 800 yards further to the swamps. We had chosen this late season of the year, in order to find the marshes reduced to their mininum; but, nevertheless, we find, were enough of them yet. Our guides now took us through canes 10 and 15 feet high, and 'Ulleik (raspberry) jungles, through which they broke paths for us, now and then passing small ditches into which we sank up to our knees and body, sliding over wet plantations of wild celery, which in these regions is abundant, or being caught by the sharp thorns of the raspberry bushes, which tore our clothes into pieces. After struggling in this way along for some hundred yards we finally arrived at a small lake of about 150 by 80 yards of clear, good water, the shores overgrown by high jungles of cane, the so-called Birket Timsâh, or "Crocodile Pool." 
This Birket was pointed out to be the regular hiding-place of the beasts, and in fact we remarked certain flat pieces of ground on the shore on which the cane was trodden down, with traces of such animals. "Here they rest and expose themselves to the sunbeams about noontime," our guides exclaimed; but, although we retired and watched in the jungle for hours, we could not discover any such animal. Ducks and water-fowls quietly crossed the pool, and crowds of white fish played in the clear water. Half a goat was now fastened to a strong hook, and with an iron chain fastened to the shore, and this bait thrown into the pool ; next morning; when we returned again, the bait was gone, but nothing caught. At our second arrival at the pool a crocodile was seen for a moment near the shore, but disappeared immediately, and never was discovered again. In order to hunt it up in the Birket itself, a boat would be required, with the aid of which the beast could easily be discovered in the clear water. All our efforts to this effect were without result. Our guides took us southwards along muddy lakes and marshy arms of the Zerka River, across which they carried us on their shoulders, often sinking in to their neck, and it was with a very mean-looking exterior that we arrived at the actual river, the vicinity and shores of which were thickly covered with low brushes of "tarfa," or tamarisks. We proceeded to several pools, crawling on our hands and feet in the mud below the tamarisk jungles in order to discover a crocodile ; but, with the exception of fine specimens of wild boar and francolins, which we shot, no other animal worth mentioning was seen. Late in the evening we arrived at the mills, "tawalin Jisr ez Zerka," at the bridge near the mouth of the river. The next morning we started in a northern direction, and explored in the same way the marshy region situate between Khurbet Kubbâra and the Tahimet esh Sheikh, a mill on the Nahr ed Dufley, so called while lying near the tomb of a Mohammedan Saint; but also these researches were resultless.

The marshes on this part of the Zôr were very much reduced, and the dam across them could be more thoroughly explored than in March, when the Palestine Surveying Party visited that region (see "Memoirs," Vol. II, p. 29, Kebârah). This ancient and very strongly built dam had, as already mentioned in the "Menoirs," the object of preventing the spreading northwards of the marsh surrounding it in the south; the natives call it Jisr el Kanâ, القسر القناء, "the Bridge of the Aqueduct," but no convincing signs of an aqueduct could be discovered. The dam is built up with large sandstones, from 3 to 6 feet in length, the height of its layers being from 16 to 28 inches, combined by good white mortar, and laid alternately as headers and stretchers. The width of the dam near its eastern end is but 3 feet, but it soon widens to a width of 8 feet 3 inches; its height varies according to the terrain from 2 to 11 feet. At such parts where the dam has the height of 8 to 11 feet, buttresses were added to the northem side, having a width of 13 feet, and projecting 3 feet 6 inches, with a slope towards its base.

The total length of this dam was about 1,400 yards. Near the middle, 

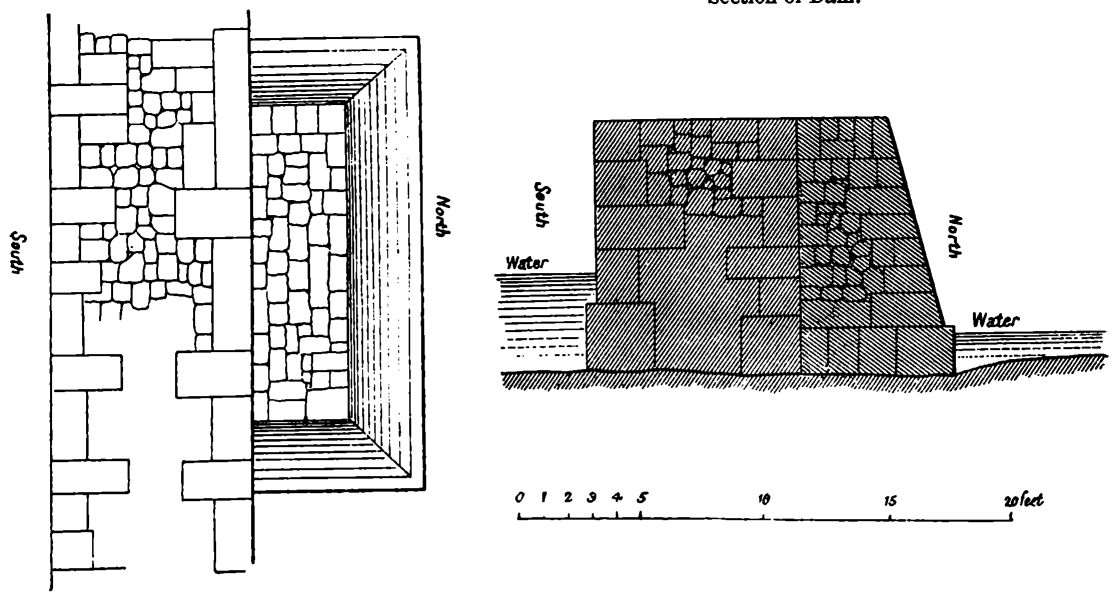

DAM ACROSB QWAMP OF THE NABR ED DUFLEY.

where the dam has its maximum height of 11 and more feet, its surface widens, and two pointed vaults were discovered. Although this part is very much fallen, the following plans could anyhow be made, which would prove that these two openings were prepared for the purpose of giving an outlet to the waters in case they should surpass their ordinary maximum height. The vaults are 6 feet 6 inches wide, and about 6 feet 3 inches high, with signs of plastering. On the southern front, across the vaults, a wall with a small rectangular open-

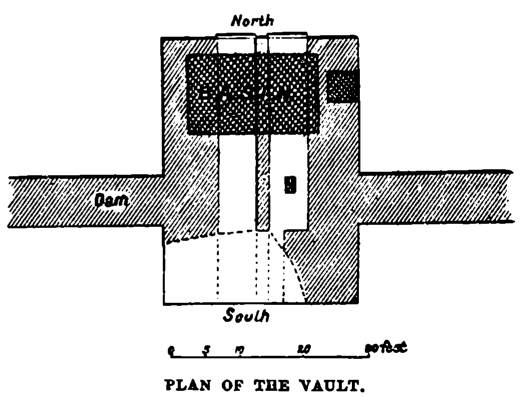

ing was added later, evidently because the vaults being found too large to answer their purpose. The dam, which has on this spot a width of 43 feet, shows on its surface remains of rectangular plastered basins, and an opening into the vaults 12 inches by 16 inches; there are also traces of a pavement to be discovered. The dam may therefore have served in the meantime as a passage, and the mentioned basins may have been wateringplaces for the animals.

The marshes and lagoons approach to both sides of the dam in winter, and never dry up entirely ; in their mud numerous herds of buffalo oxen wallow.

From the dam we returned to our camp near Khurbet en Nazle (Sheet VIII), a ruin with scattered large building stones and caves. Between this ruin and Khurbet el Ehdeithiyeh (Sheet VIII), on the main road, a 

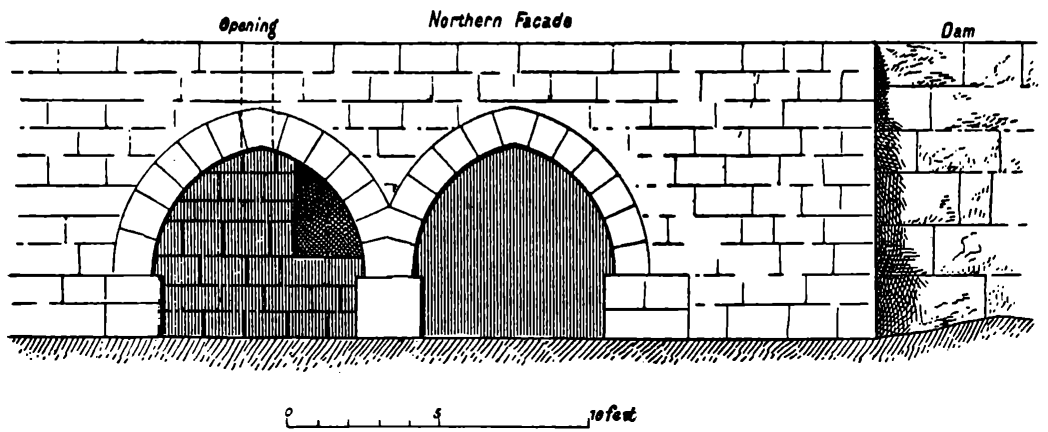

$s$

10fent

VAOLTS AND DAM ACROSS THE SWAMP.

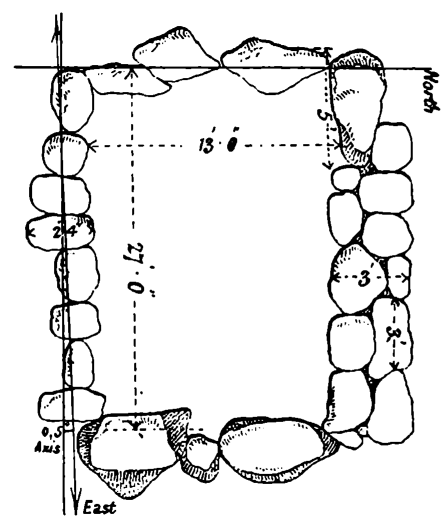

rectangular room surrounded by large unhewn limestones, evi dently an ancient burial-place, was discovered. The bearing of main axis was exactly from east to west (east $180^{\circ}$, west $5^{\circ}$ ); the eastern and the western ends are marked out by uncommonly large stones, 5 and 3 feet long, 2 and 3 feet high, the length of the grave being 27 feet, its breadth 13 feet.

A little east of Kh. el Hadeithiyeh, on the foot of the Carmel ranges, I opened several caves, the openings of which were partly filled up with rubbish, partly overgrown with Serrîs. An exploration of the interior proved that these openings all belong to one very extensive cave, whose artificially worked main entrance faced the
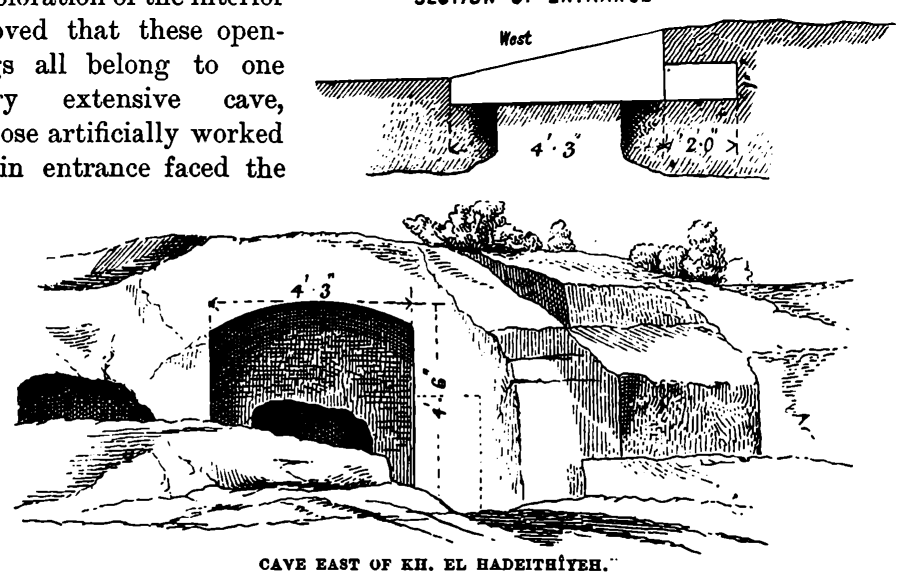

CAVE EAST OF KH. EL HADEITHIYEH." 
ruin towards west. The interior is in a totally fallen state, and filled up with fragments of a rock-hewn ceiling, rubbish, and mud; near the floor signs of a loculus can be discovered; the rock, being a soft Nari limestone, crumbles rapidly. The western main entrance shows a rockcut arched gateway, 4 feet 3 inches wide, and yet 4 feet 6 inches high, with a sided bay to the right, into which a slab was placed in order to close the cave.

On the ruin itself nothing but traces of well-built walls and one column-shaft could be found; it is intended to build some huts on this site, which now belongs to the Jewish Colony at Zimmarîn.

From our camp we proceeded southwards down to the Burj en Nisr the "Eagles Rock," a precipice below Khirbet Mansur el 'Akab (Sheet VII), the extreme south-western end of Mount Carmel, renowned for the great number of eagles, nestling in the natural caves of the rock; and from here to the Tahunet Abu Nur, a mill built on the Nahr ez Zerka, and followed the course of the river down to its mouth nearly; but our researches as to crocodiles were without result: all we came across were ditches, swamps, and jungles of tamarisks. I therefore hesitate to believe, as generally said, that these creatures are numerous in the marshes of the Zerka, and although their existence cannot be denied, their number must have been reduced to a couple or so.

From the mill above mentioned we followed the river upwards to Miyamâs. The description of its theatre can be found in the "Memoirs," Vol. II, pp. 66, 67; the ancient site, as well as the theatre, is now built over by a fine grain-store belonging to a rich merchant of Haifa, and next to it a village of twenty huts has been erected. The ground near, marshy in winter, has been drained and cultivated, and the gardens of el 'Ayun replanted with fruit trees. The theatre has been partly broken down and the building stones used elsewhere; the interior vaults are prepared to serve as barns and stores; the "arena" forms the courtyard of the place, where its master receives the tenths, and judges over his fellahin. Near the gardens large white marble columns were excavated, and several ancient tombs opened; each of these tombs had a large stone cover; the grave itself was sunk into the ground and built up with masonry.

The spelling of the name of this ancient site is, according to my collection

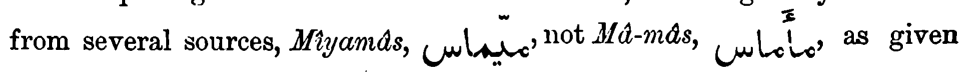
in the Name Lists of the Palestine Map (Vol. Name Lists, page 151), and would in this corrected spelling resemble the Jewish " Majumas' still more.

Not only this ruin has been settled since the Palestine Map was edited, but also the following old sites situate in its neighbourhood (marked "Ruins" on the map) :-

2. Zimmarin (Jews) ....130 houses, built in European style.

3. Ez Zerghanîyeh .... 20 huts and a large granary.

4. El Bureij .... .... 30 huts (a flourishing village, with a mosque, a fine granary, dwelling and garden of el Haj Amin Agha). 
5. Burj el Kheil … 12 huts, moderate village.

6. Umm el'Alak … 18 huts, well-built houses and granary.

7. Kaisdrieh (Cæsarea) 22 well-built houses with tile roofs ; Bosniaks.

The soil around the Nahr ez Zerka is most fertile, but the climate very feverish. A few years ago wealthy people of Haifa and Acca had

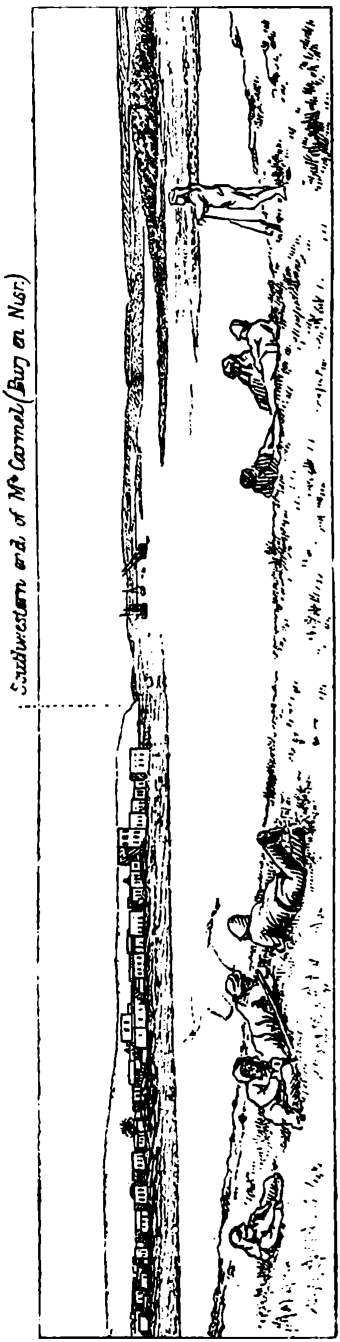
taken possession of these lands and began to drain the marshy region with the aid of experienced farmers, and to cultivate the soil with European agricultural implements. Should they continue to purify this region in the manner they have thus commenced, I have no doubt that this spot, for its abundance of good water and soil, will soon be the most thickly settled one in this. part of Palestine.

From the Zerka River we took our way i homewards again by the way of Tantara (Sheet VII, "Memoirs," Vol. II, page 7). This village is still increasing, and goodlooking granaries rise near the seashore, whence grain is exported in small sailing vessels, generally to Esh Shany near Beirat; the vessels anchor between the isles and the shores. But the more the village grows, the more the ancient remains disappear from near the isolated old tower to the north of Tantara ("Memoirs," Vol. II, p. 7). The large blocks formerly built into the city wall near the shore are taken one by one away to Jaffa and other places.

Our road led us further on to Kefr Lâm and to Sheikh Abrâk, also called Khurbet Malhâh on Sheet V and "Memoirs," Vol. I, page 314 ; the latter name, Mâlhah, which I could not learn from the natives myself, who merely call the ruin Khurbet esh Sheikh Abrâk, may possibly be derived from the fact that the ancient sarcophagi and holes in the rocks near it are used to a wide extent as salt basins, that is, into which sea-water is poured in order to obtain cooking salt by the evaporation of the water by the sun ; this trade is practised all along the coast, and such places generally bear the name Mallâha.

The various characters of ancient tombs found at this site are noted in the "Memoirs," Vol. I, page 315, but it seems uncertain whether the cave, 
the entrance of which I opened, has already been explored; this cave has the distinct form of a cross, and is reached by a stairway and a rectangular rentrance under an arch cut out of the rock. No signs of a stone gate exist.

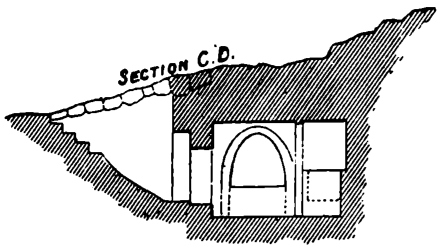

$\cdot$

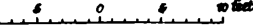

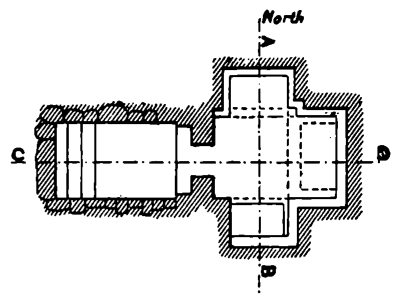

SECTION A.P.

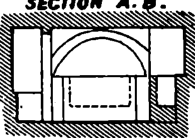
from north to south, and 10 feet 3 inches from east to west, the main axis being oriented from east to west. The interior is worked as a cross-vault ; under each of the three arcosolia we find a loculus, elevated 3 feet 8 inches above the ground, the total height of the cave being 7 feet 6 inches.

From Khurbet esh Sheikh Ibrâk we still proceeded northwards towards "Atplit, and before reaching this town I discovered, some 800 yards south of it (near Bîr el Yezek), the tracing of a very strong wall, built up with mighty unhewn stones, running from east to west across the range of low hills :separating the Zôr of 'Atplit from the actual plain; this wall may have formed part of the outworks of the fortress. Strolling along these hills, between the Bîr and the rock-cut passage of 'Atplit, I struck upon a fallen dolmen, situated on the shoulder of them ; the side-stones were still in good order, but the top-piece fallen down. 'Atplit itself is, as before, a poorlooking, miserable village, with scarcely any recent progress to be observed; some 50,000 of the ancient large building stones of the cathedral and fortress were sold lately by the Government of Haifa to that of Jaffa, in order to build a Quay and custom-house at that port.

\section{(II.) TIBERIAS AND ITS VICINITY.}

The construction of carriage roads in the Liva of 'Acca now and then leads to interesting discoveries. One of these roads was commenced at the western gate of Tiberias, taking a western course up the mountain, and in cutting through an elevation near the gate, an extensive, very ancient Jewish cemetery, was discovered, which could be followed up to a distance of about 600 yards from the gate. The graves were some 2 or 3 feet below the ground, one built close to the other, in rows of three and more, and only separated by a wall of 1 foot 4 inches: the width of each grave was 1 foot 8 inches, its length up to 7 feet, and its depth generally 2 feet. 
The building material was composed of hewn and unhewn basaltic stones, and a white, good mortar; the interior of the grave was plastered. Similar

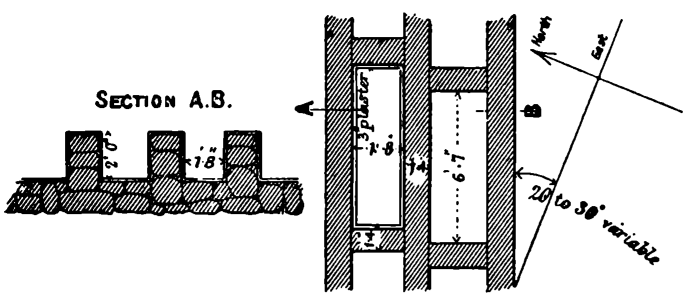
graves were also found within the present city wall. Large slabs lying about prove that they formed the cover of the graves. Next to these rows of graves, which evidently belonged

to a poorer class of people, handsome sarcophagi were found, cut out of a limestone of white colour, the rock of which exists near the hot baths. They were lying in disorder about, 1 to 3 feet below the surface, covered by large basaltic and limestone slabs; a regular orientation could not be made out, but most of them faced the east with the head end. Their length varies from 4 feet 3 inches to 7 feet 1 inch, their width from 2 feet to 2 feet 4 inches, their height from 2 feet to 2 feet 3 inches. The head end shows in its interior a cushion, and is generally round, while the foot end is square; on some, both ends are rounded. The long sides of the sarcophagus now and then show a relief ornament with a tablet, but no inscription; the ornament is elevated but 3 inches, and quite prinitive. Top and foot are distinguished by a simple moulding.

Some of these sarcophagi were taken to the Serail in order to be preserved, others were broken to pieces.
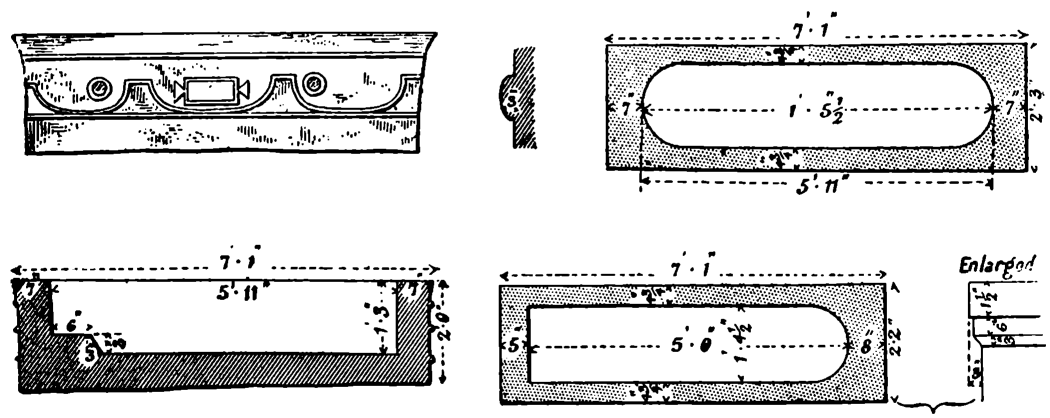

BARCOPHAGI FOUND AT TIBERIAS.

The ornaments of these sarcophagi, as well as their entire arrangement, are very closely similar to those which I found at Kala'at el Husn, on the other side of Lake Tiberias, the supposed Gamala of Josephus (see Schumacher, "Der Djaulân," 1886, Leipzig).

In walking one evening along the new road at Tiberias up the slopes of the hills, I was struck by the sharp and regular shadows which were thrown by a part of the summit of the Herod Mountain, or Kasr Bint el 
Melek, which rises between the hot baths and the city, and which by this illumining of the sinking sun clearly indicated the outlines of a rampart running around the summit of the mountain. As, on my return home, I found only a very brief account of this site in the "Memoirs" (Vol. I, p. 412), I again proceeded to the place and followed the ancient traces of the wall up, which I hereby reproduce, together with a sketch of the adjacent slopes.

This wall of Kasr Bint el Melek, the supposed mountain of Herod, surrounds, as before said, the upper part of a steep and bold hill, the lower and eastern part of which is formed by inaccessible rocks, into which numerous caves are worked, partly by nature, partly by men. In the south, where the rocks contract into a narrow shoulder, the mountain is bordered by a wâdy, and a path leads up along it in numerous serpentines to the plateau; also on the north a road runs along the slopes of the mountain, which are also bordered by a wâdy. Both watercourses rise very near each other. At one point in the west there is but a narrow neck between ; this neck widens towards the east, and becomes a kind of plateau from which rises the summit of the hill, which still shows a large amount of ancient building stones, evidently the most important point of the site. From this summit the mountain rapidly falls off towards east, south, and north, and a wâdy divides the slope, surrounded by the wall, into two halves. The Kasr, therefore, was only accessible from its western and southern slopes, while the other portions were defended by high cliffs. The rocks are limestone.

Coming from the western gate of the city of Tiberias, the ancient city wall can be followed up to the cliffs of the mountain above described. Above the cliffs traces of a well-built wall, 60 yards long, run up the steep slope to a point where it unites with the actual fortification wall of the Kasr. Here the remains show a wall 8 feet 6 inches thick, built up with small basalt building-stones, 1 and 2 feet square, set in a good white mortar, but which now begins to decay rapidly. Portions of the wall rolled down into the wâdy bed, detached by the earthquake of 1837 . The construction of the wall is exactly the same as that of the remains found between the city and the hot baths, along the shore of the lake. The wall now runs into two directions, eastwards and westwards, round the summit; in its western course arriving at the described neck, where the plateau is easily accessible, it ends in a square tower of 23 feet, now fallen to a height of a few yards above the terrain, of the same construction as the wall, and bends nearly in a rectangle southwards and south-eastwards, showing along its course another square tower; from here the slopes begin to become steep to the right and left; falling off into wâdies, the wall diminishes into a width of 6 feet 6 inches and less, and winds round the natural construction of the mount until it joins the other half, which in a similar way followed the eastern and north-eastern slopes. The western and southern wall yet stands, generally to a height of a foot or two, and can therefore be easily followed. The eastern and north-eastern wall is totally ruined, and scarcely the traces can yet be discovered; this portion, standing just above 
the cliffs, was less strong, and built up with evident little care. From where the actual fortress wall closes, a line still continues winding down finally to the plain, and then to the lake shore, where it unites the wall bordering the lake. Reading the above description over again, I find that I must add that the actual large city wall began at a point near the present town in the west, followed the foot of the mountain up to the cliffs of Kasr Bint el Melek, and then from there winded westwards round the projecting hill, embracing thus one of the most conspicuous points of the vicinity, and, running down its southern slopes again, joined at the lake shore that portion of the city wall which followed the shore up to the present town. The conspicuous mount itself, rising to a maximum height of about 580 feet above the Lake of Tiberias, received its own surrounding wall and castle, and thus by its fortified and elevated position formed the Acropolis of the city. The length of this city wall, in all, would be about three English miles; that embracing the Kasr Bint el Melek alone, 1,040 yards. Within the wall of the latter but few ruins were found. The most important one, now merely a large heap of hewn stones, and some basalt columns, occupies the highest point of the mountain ; the few traces found cannot lead to any plan of the former building. On the western foot of this elevated ruin we remark a square subterranean building, 26 feet by 23 feet, with remains of plastering and a projecting pillar, probably of a former vault ; the interior of this basin is filled up with débris. Little to the south of it a circular basin, measuring 4 feet 9 inches in diameter, and yet 6 feet deep, was found. The interior is also plastered, the building work circumfering the basin is of good masonry; on its surface several worked channel lead into the direction of the described neighbouring square building. Both basins may have been used for water supply. Walking still along the wall until the middle tower of the south is reached, a third square building, 49 feet by 23 feet, occupies the borders of a small plateau; its masonry work is strong, the walls having a thickness of several feet. In the interior of the Acropolis wall no other remains of interest were found. Portions of masonry work, broken column-shafts of basalt, and building stones lie in heaps in the wâdy bed; but no ornament whatever could be discovered to give an idea of its building area. But there is no doubt that the whole terrain, being included by the wall, was never covered with buildings, and that the few single that have been erected manifest a fortified character and position. Kasr Bint el Melek, therefore, was no city, but, as its name gives, a fortress, probably Herod's castle, destroyed by Josephus.

In passing outside of the Acropolis wall to the south, the general city wall serpentines along a thin neck, separating two wâdies; at this point another subterranean square basin, and near by traces of a building were remarked.

At the eastern foot of the Kasr the most remarkable ruins of the ancient city are found, among which the recently restored and greatly venerated Mohammedan sanctuary of the Sitt Iskeiney rises. It may be hoped that in constructing the new road across this field of ancient 


\section{SKETCH 'FF KUSR BINT EL MELEK}

\section{OR MOUNTAIN OF HEROD.}

1

By G.Schumacher

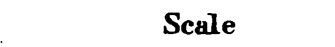

\begin{tabular}{llllll}
\hline & 100 & 200 & $400 \quad 600$ & 800 & \\
\hline
\end{tabular}
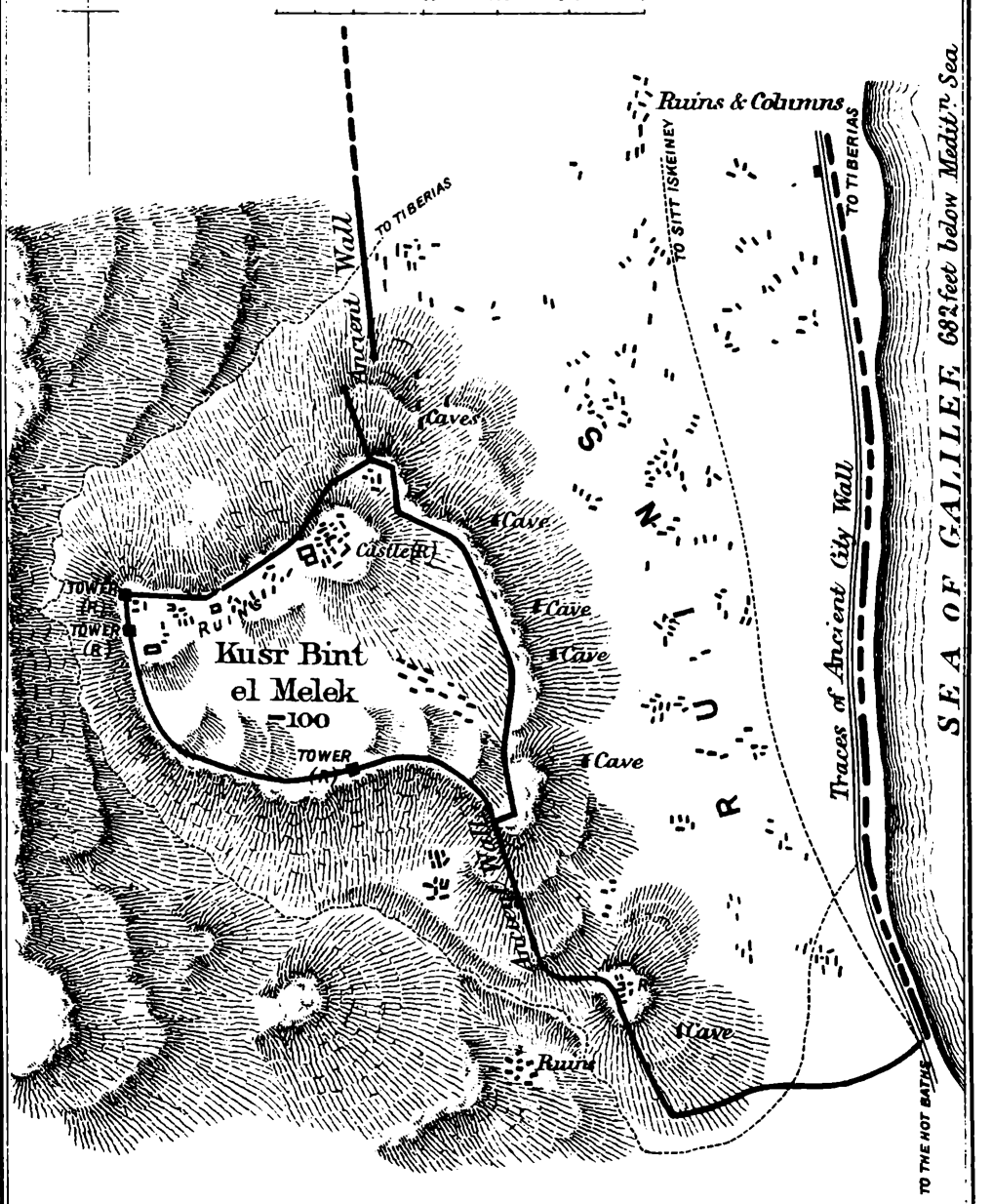

Trementasiay sorith 
remains, between Tiberias and the baths, most interesting discoveries will appear.

While taking a walk through the city-the exact population list of which will be prepared for my next report-I remarked several old stones excavated in the vicinity of Tiberias; one of them I found in the yard of the Reïs el Beledîye (city major), whence it was excavated, which bears the following interesting Arabic inscription :-

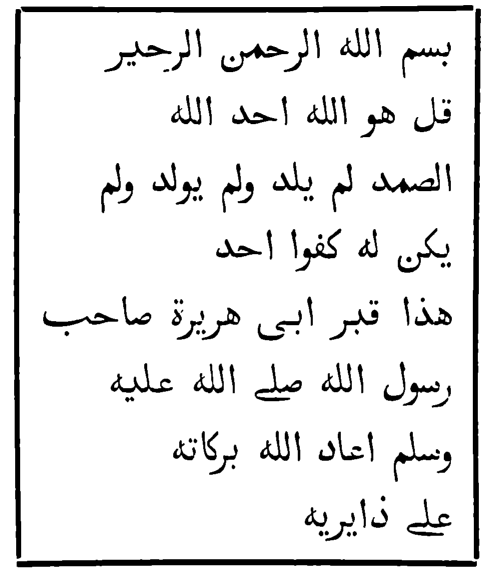

The stone is of 'Ajlan marble, and measures 2 feet 7 inches by 2 feet. This inscription, which renders that it designated the grave of $A b u$ Hureira, "the friend of God's disciple," was found interesting enough to be sent to the 'Ulema (Mohammedan learned men) of Damascus, and to inquire how this is to be understood; for, according to Mohammedan tradition, Abu Hureira died and was buried at Medina. The 'Ulema briefly replied that the inscription was erroneous and false; but the Mohammedan Mufdi, or priest of Tiberias, was not contented therewith, and sent a copy to Constantinople. Should the inscription be trustworthy, and could it on the hand of the history be authenticated, Tiberias would soon become the character of a great Mohammedan place of pilgrimage. It would be very interesting to make historical researches thereon, which $I$ here, in the absence of any library, am not able to do. I carefully investigated the place where the stone was found, and discovered infallible signs of an ancient mosque, as the prayer niche in a southern ancient wall, an opening to the north, parts of a cupola, and the top-stone or crown which usually omaments the $J a m a^{\prime}$ vault. I should gladly wish Tiberias a better

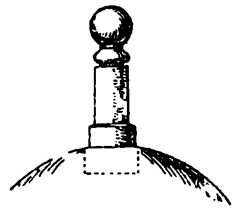
link than it hitherto had, for it is in great want of a flight.

Another stone, basalt, which, according to what I was told, has been excavated near the western gate, bears the following Greek inscription :- 


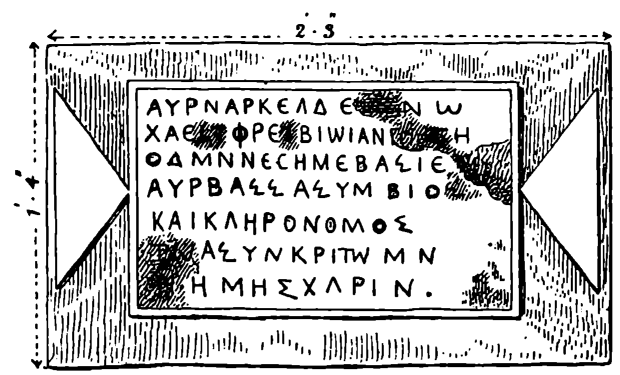

A third stone, a marble column with a Hebrew inscription, has been excavated near the southern Jewish cemetery, but the inscription proved to be modern.

Haifa, November, 1886.

G. Schumacher.

NOTICES OF THE DOME OF THE ROCK AND OF THE CHURCH OF THE SEPULCHRE BY ARAB HIS. TORIANS PRIOR TO THE FIRST CRUSADE.

\section{Translated by Guy le Strange.}

"No Mohammedan writer of any sort, anterior to the recovery of the city from the Christians by Saladin, ventures to assert that his countrymen built the Dome of the Rock."

The object of the present paper is to show how utterly incorrect is this statement made by the late Mr. Fergusson in support of his theory that the Dome of the Rock (and not the present Church of the Holy Sepulchre) represents the Basilica erected by Constantine.

Whatever may be the arguments based upon the architectural style of the Dome of the Rock, it may be hoped that the passages here to be quoted, once and for all, will show that the historical evidence runs exactly counter to Mr. Fergusson's ingenious theory.

Within less than two centuries of the building of the Dome of the Rock by the Caliph 'Abd al Malik we have an account (Al Yakubî) detailing the circumstances that led to its erection.

Thirty years later there is a minute description of the building (Ibn al Fakih), showing that the present edifice is almost intact, that of 'Abd al Malik; and a work written by a Spanish traveller of about the same date proves that many of the other buildings occupying the Haram Area were displaced neither during the Crusaders' occupation, nor at the restoration under Saladin.

1 Article Jerusalem, in "Smith's Dictionary of the Bible," rol. i, p. 1030. 